Short Report

Open Access

\title{
Angiotensin-converting enzyme inhibitory effects of dairy- and soy-derived peptides in pre-hypertensive overweight men and women
}

\author{
Melissa S. Munn ${ }^{1}$, Shalamar Sibley ${ }^{2}$, Richard Brundage ${ }^{3}$, Baraem Ismail ${ }^{1}$, Carrie P. \\ Earthman $^{1}$
}

${ }^{1}$ Department of Food Science and Nutrition, University of Minnesota, 1334 Eckles Avenue, Saint Paul, MN 55108, USA; ${ }^{2}$ Department of Medicine, University of Minnesota, 420 Delaware Street, SE, Minneapolis, MN 55455, USA; ${ }^{3}$ Department of Experimental and Clinical Pharmacology, University of Minnesota, 717 Delaware Street SE, Minneapolis, MN 55414, USA

*Corresponding Author: Carrie P Earthman, PhD, RD, University of Minnesota, Department of Food Science and Nutrition, 1334 Eckles Avenue, St. Paul, MN 55108, USA

Submission date: December 18, 2012, Acceptance date: January 24, 2013; Publication date: January 27, 2013

\section{ABSTRACT:}

Background: Hypertension is considered the most prevalent cardiovascular disorder and a significant public health problem. A functional food that could potentially impede progression into a hypertensive state in pre-hypertensive individuals is of significant interest to clinicians and consumers. In vitro and animal studies suggest the presence of potential ACE inhibitory dairyand soy-derived peptides. Very few human-based research studies have been conducted to investigate the blood pressure lowering and/or ACE-inhibitory effects of whey and soy protein hydrolysates in humans. This pilot study tested the acute effects of $20 \mathrm{~g}$ doses of whey and soy hydrolysates in pre-hypertensive, overweight men and postmenopausal women on serum ACE activity and blood pressure.

Findings: Using a randomized crossover design, four initial subjects received five treatments (unhydrolyzed casein, whey protein isolate, whey protein hydrolysate, soy protein isolate, soy protein hydrolysate) at different testing visits separated by three-day washout periods. Blood pressure and blood draws to measure ACE activity were taken at thirty minute intervals following treatment consumption. Both the soy protein and whey protein hydrolysates had notable in vitro ACE-inhibitory activity, both before and after heat treatment. No differences were observed among the protein treatments for either ACE activity or systolic blood pressure.

Conclusions: The results of this pilot study support a discrepancy between in vitro and humanbased in vivo ACE-inhibitory acute effects of whey and soy protein hydrolysates, underscoring the need for further research to better understand potential explanations for these findings. 
Key Words: ACE (Angiotensin-converting enzyme), Casein, Soy, Whey, Protein, Blood pressure, Dairy, Bioactive, Peptides

\section{INTRODUCTION:}

The renin-angiotensin-aldosterone system (RAAS) primarily increases blood pressure by producing the vasoconstrictor angiotensin II, facilitated by angiotensin-converting enzyme (ACE). Researchers have found antihypertensive potential in dairy-derived peptides [1-6]. The development of functional foods that may prevent hypertension in pre-hypertensive individuals is intriguing. We investigated the effects of an acute dose of whey- and soy-derived bioactive peptides on ACE activity and blood pressure in pre-hypertensive, overweight men and postmenopausal women.

\section{METHODS:}

Study Overview: This randomized, single-blind cross-over study compared whey protein hydrolysate (WPH), whey protein isolate (WPI), soy protein hydrolysate (SPH), soy protein isolate (SPI), and casein at $20 \mathrm{~g}$ doses, an amount expected to elicit a biological effect based on a study reporting significant blood pressure reduction in humans consuming $20 \mathrm{~g}$ WPH for six weeks [7]. To determine acute effects, measurements were taken up to 180 minutes posttreatment. See Figure 1 for study design.

\begin{tabular}{|l|l|l|l|l|l|l|l|l|l|}
\hline \multicolumn{2}{|l|}{ Controlled Diet } \\
$\begin{array}{l}\text { Pre- } \\
\text { Testing } \\
\text { Week 1 }\end{array}$ & Visit 1 & $\begin{array}{l}\text { 3Day } \\
\text { Wash } \\
\text { Out }\end{array}$ & Visit 2 & $\begin{array}{l}\text { 3Day } \\
\text { Wash } \\
\text { Out }\end{array}$ & Visit 3 & $\begin{array}{l}\text { 3Day } \\
\text { Wash } \\
\text { Out }\end{array}$ & Visit 4 & $\begin{array}{l}\text { 3Day } \\
\text { Wash } \\
\text { Out }\end{array}$ & Visit 5 \\
\hline $\mathrm{X}$ & SPH* & $\mathrm{X}$ & WPI* & $\mathrm{X}$ & SPH* & $\mathrm{X}$ & Casein* & $\mathrm{X}$ & SPI* \\
\hline
\end{tabular}

Figure 1. Study Design: A Sample Schedule

*Each subject received the five treatments in a randomized order, each at a different visit: soy protein isolate (SPI), soy protein hydrolysate (SPH), whey protein isolate (WPI), whey protein hydrolysate 
(WPH), casein. A controlled diet was followed throughout the study, beginning one week before testing; treatments were separated by 3 -day washout periods. X: No treatment received

Subject Selection: Subjects were recruited through University of Minnesota Institutional Review Board (IRB)-approved campus fliers. The study protocol was reviewed and approved by the IRB and the Clinical and Translational Science Institute at the University of Minnesota. See Table 1 for recruitment eligibility.

Table 1. Study Eligibility

\begin{tabular}{ll}
\hline Body mass index $(\mathrm{BMI})$ & $25-34.9 \mathrm{~kg} / \mathrm{m}^{2}$ \\
Age & $\geq 40$ years \\
$\mathrm{SBP}^{* ¥}$ & $\geq 90$ but $\leq 139 \mathrm{~mm} \mathrm{Hg}$ \\
and/or & $\leq 90$ but $>80$ \\
$\mathrm{DBP}^{\dagger ¥}$ &
\end{tabular}

Pertaining to females only:

No Menses for $\geq 12$ months

No hormone replacement therapy medications

Had a complete hysterectomy $\geq 12$ months prior to enrollment

\footnotetext{
*SBP: Systolic blood pressure

'DBP: Diastolic blood pressure

${ }^{¥}$ Taken as the mean of 2 readings
}

Testing Visits: Subjects arrived to the DCRU by 0700 fasted from 1900 the day before and were instructed to lie supine with one pillow beginning 30 minutes before baseline, after which blood pressure assessment and blood draw for ACE activity were performed. Subjects consumed one of the five randomly assigned treatments, after which the Time 0 was marked. Blood sampling occurred at 30-minute intervals from Time 0 to 180 minutes, determined from a small preliminary study where nine subjects received $20 \mathrm{~g}$ of one of the treatments and blood collection occurred at 15- and 30-minute intervals up to 300 minutes.

Controlled Diet: DCRU Nutrition Services designed a controlled diet to meet individual energy needs that was whey-, soy-, and dairy-free, providing $1 \mathrm{~g}$ of sodium and $1.5 \mathrm{~g}$ of potassium per 1,000 calories. All meals were provided and subjects were to report off-plan intake on food records and to return remains.

\section{Production of hydrolysates:}

Davisco Foods International, Inc. (Eden Prairie, MN) provided the WPI (BiPro) and WPH (Biozate 1). Archer Daniels Midland Company provided defatted soy flour samples (Decatur, IL). Minimally heat-treated and defatted soy flour was used to prepare SPI following methods 
outlined by Tsumura et al [8]. Produced SPI was used to prepare SPH following selective hydrolysis with papain, mainly targeting hydrolysis of the $\beta$-conglycinin component [9].

Production of treatment cookies: Whey-derived peptides are typically delivered in beverages [3,7]. The insolubility of SPH in liquid and desire for optimal palatability influenced our decision to utilize the unique delivery form of a cookie. Twenty grams of the protein were divided into four cookies (Table 2) baked in a conventional oven at $449.7 \mathrm{~K}$ for seven minutes.

Table 2. Protein Treatment Ingredients

\begin{tabular}{|l|l|}
\hline Ingredient & Amount (g)* \\
\hline Protein** & 24.83 \\
\hline Butter & 21.59 \\
\hline Starch & 21.59 \\
\hline Brown sugar & 16.198 \\
\hline Splenda & 1.94 \\
\hline Baking soda & 0.539 \\
\hline Baking powder & 0.269 \\
\hline Almond flavor & 0.2159 \\
\hline Vanilla flavor & 2.159 \\
\hline Walnut oil & 2.159 \\
\hline Water & 18.358 \\
\hline Chocolate chips $^{*}$ & 15.118 \\
\hline Total $^{+}$per cookie & $125^{++} 28.94^{++}$ \\
\hline
\end{tabular}

* Amounts have been scaled up to account for losses during preparation

** Casein, soy protein hydrolysate, soy protein hydrolysate, whey protein isolate, or whey protein hydrolysate

${ }^{+}$Total weight of dough before dividing into 4 cookies

${ }^{++}$Weight of each of the 4 cookies

In vitro ACE inhibition of hydrolysates before and after heating: ACE inhibitory activity measurements of the hydrolysates were conducted, in triplicate, following the assay outlined by Otte et al [10] and Shalaby et al [11] using FA-PGG as substrate, with modifications adapted from Margatan et al [9]. The influence of thermal or $\mathrm{pH}$ instability on bioactivity or digestive survivability of peptides after baking is uncertain; therefore, SPH ACE inhibition was tested post thermal treatment similar to cookie baking conditions. In vitro inhibition was unaffected by heat treatment (data published elsewhere) [9]. 
Plasma ACE Activity Assay: At each time point, blood was collected (5mL), clotted, held at room temperature, and cold spun at $2091 \mathrm{RCF}$ for 10 minutes. Serum $(1 \mathrm{~mL})$ was aliquotted into cryogenic vials in duplicate, flash frozen with dry ice and alcohol, and stored at $210.8 \mathrm{~K}$ before shipment on dry ice to ARUP Laboratories (Salt Lake City, UT).

Statistical Analysis: Area under the curve (AUC) was calculated for each subject and treatment for ACE activity and systolic blood pressure (SBP) from baseline to 180 minutes ((Phoenix WinNonlin 6.3, Mountain View, CA, USA)). Because in vivo digestion of WPI, SPI, and casein could yield ACE-inhibitory peptides, differences across all treatments for both endpoints were evaluated using repeated measures ANOVA with post-hoc comparisons ((GraphPad InStat version 3.10 for Windows (GraphPad Software, San Diego California USA, www.graphpad.com)). Significance was set at $\mathrm{p}<0.05$.

\section{RESULTS:}

In vitro ACE inhibition of the SPH and WPH samples were similar, $\left(\mathrm{IC}_{50}\right.$ of $0.177 \mathrm{mg} \mathrm{SPH}$ protein $/ \mathrm{mL}, 0.200 \mathrm{mg}$ WPH protein $/ \mathrm{mL}$ [9] and fell within the reported range of $\mathrm{IC}_{50}$ values for ACE inhibitory peptides $(0.046-0.930 \mathrm{mg}$ protein $/ \mathrm{mL})$ [12-16]. No adverse events were reported, treatments were tolerated, and compliance was good. However, logistical challenges with study continuation encouraged an interim analysis of data from the first four subjects. A lack of significant differences between treatment proteins on either endpoint halted subject recruitment. Data from these four subjects are presented. See Table 3 for subject characteristics. Graphical representation of mean ACE activity (Figure 2) and SBP (Figure 3) over time, illustrate the variability among treatments.

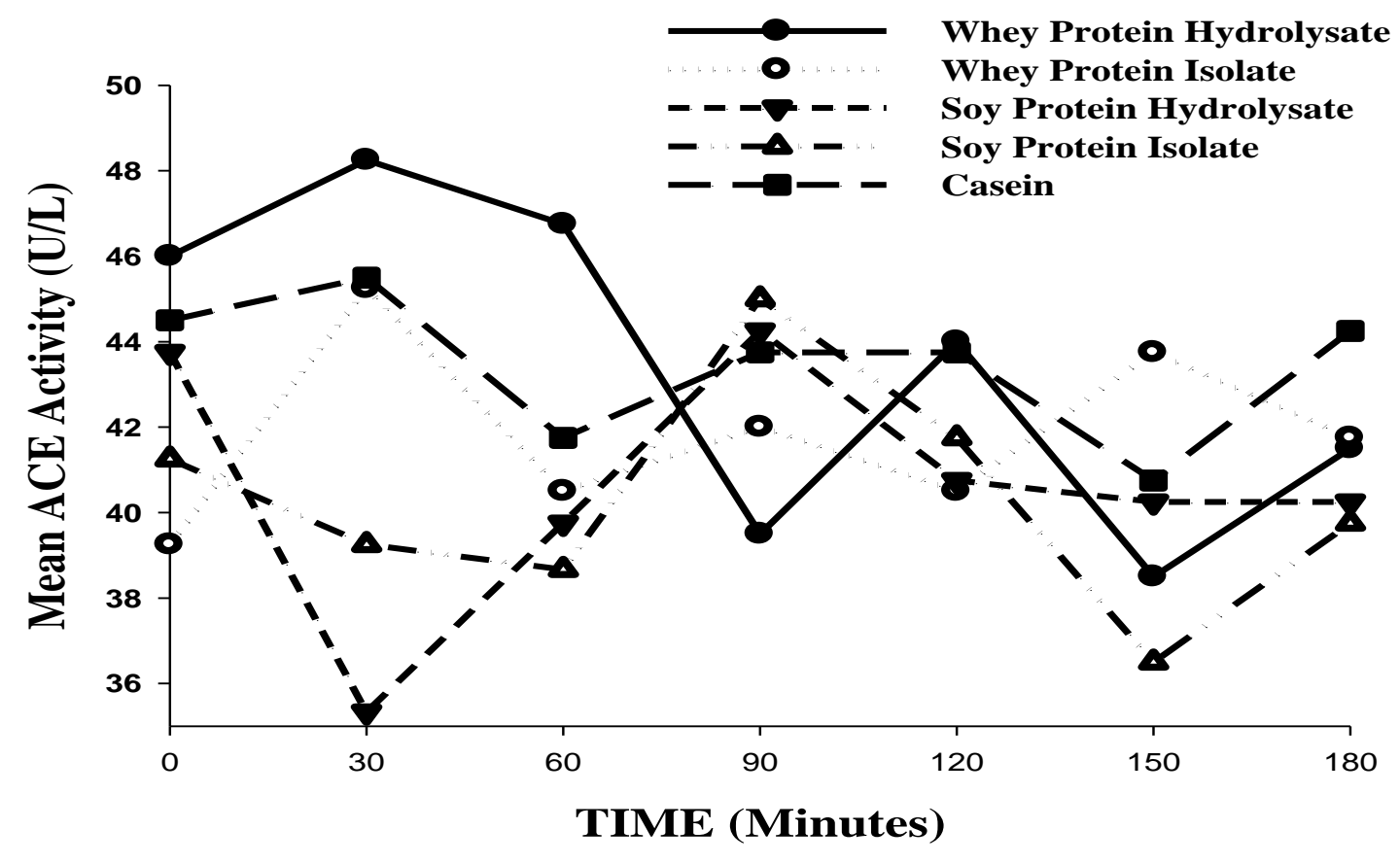

Figure 2. Mean ACE Activity vs Time by Treatment 


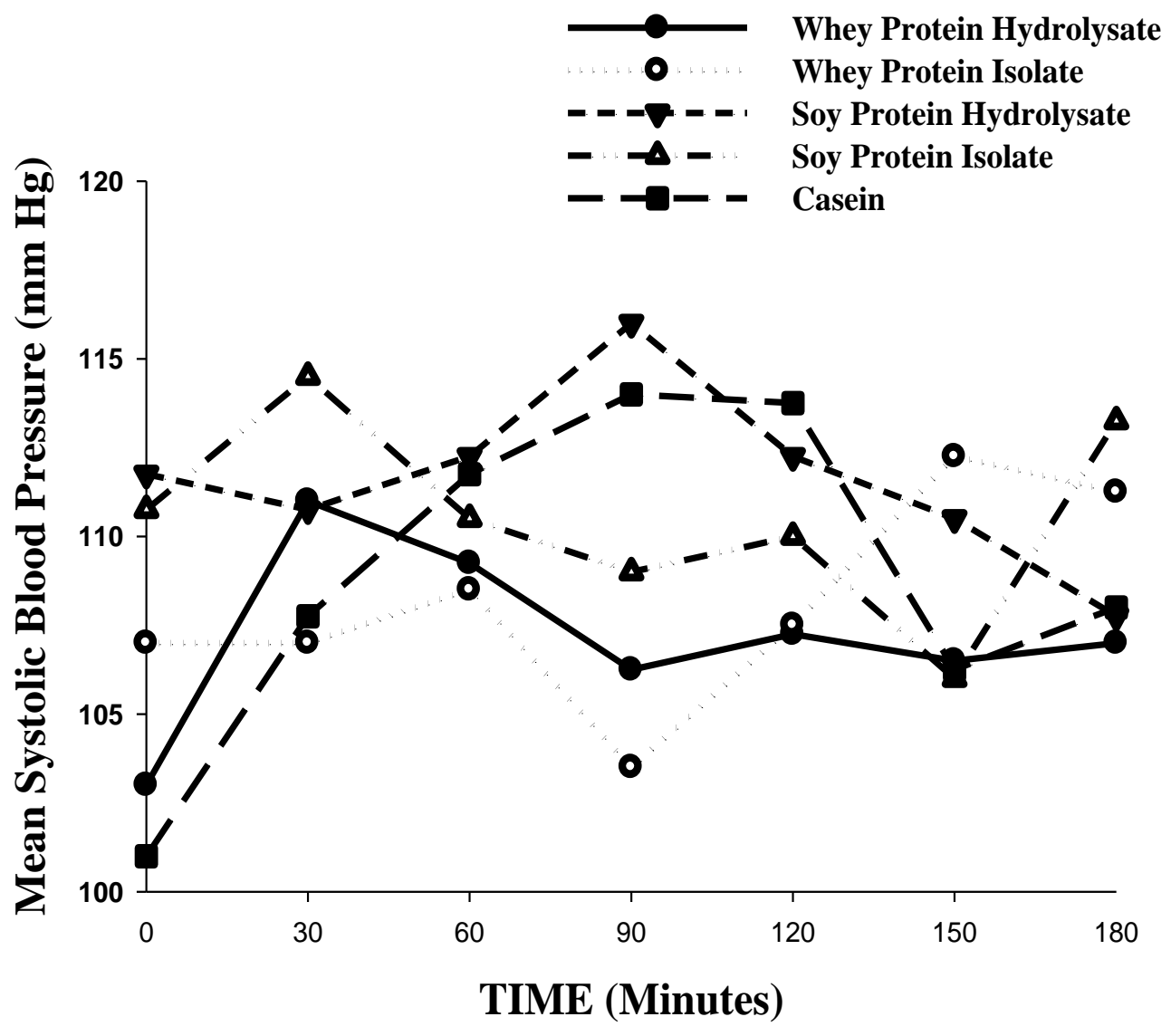

Figure 3. Mean Systolic Blood Pressure vs Tme by Treatment

Table 3. Subject Characteristics

$\begin{array}{cc}\mathrm{N} & 4(2 \mathrm{M}, 2 \mathrm{~F}) \\ \text { Age }^{*} & 58 \pm 1.3 \text { years } \\ \text { BMI }^{*} & 28 \pm .7 \mathrm{~kg} / \mathrm{m}^{2} \\ \text { SBP }^{*} & 118 \pm 7 \mathrm{~mm} \mathrm{Hg} \\ \text { DBP }^{* \dagger} & 81 \pm 6 \mathrm{~mm} \mathrm{Hg}\end{array}$

*Mean \pm standard deviation

$\uparrow$ Prehypertension may be defined by a DBP $>80 \mathrm{mmHg}$ 
Table 4. Angiotensin-Converting Enzyme (ACE) Area-Under-the-Curve (AUC) by Treatment

\begin{tabular}{|c|c|c|c|}
\hline Treatment & Subject ID & $\begin{array}{l}\text { AUC 60-180 } \\
\text { min }\end{array}$ & AUC 0-180 min \\
\hline \multirow{6}{*}{ Casein } & 85001 & 3825 & 6150 \\
\hline & 85004 & 5445 & 7980 \\
\hline & 85005 & 7110 & 10785 \\
\hline & 85007 & 4170 & 6270 \\
\hline & Mean & 5138 & 7796 \\
\hline & SD & 1488 & 2161 \\
\hline \multirow{6}{*}{ SPI } & 85001 & 3405 & 4845 \\
\hline & 85004 & 4845 & 7290 \\
\hline & 85005 & 6892.5 & 10485 \\
\hline & 85007 & 4575 & 6900 \\
\hline & Mean & 4958 & 7429 \\
\hline & SD & 1620 & 2272 \\
\hline \multirow{6}{*}{ SPH } & 85001 & 3405 & 4845 \\
\hline & 85004 & 4845 & 7290 \\
\hline & 85005 & 6892.5 & 10485 \\
\hline & 85007 & 4680 & 7035 \\
\hline & Mean & 4956 & 7414 \\
\hline & SD & 1443 & 2323 \\
\hline \multirow{6}{*}{ WPI } & 85001 & 3885.00 & 5475.00 \\
\hline & 85004 & 5490.00 & 8310.00 \\
\hline & 85005 & 6630.00 & 10335.00 \\
\hline & 85007 & 4080.00 & 6180.00 \\
\hline & Mean & 5021.250 & 7575 \\
\hline & SD & 1289 & 2200 \\
\hline \multirow{6}{*}{ WPH } & 85001 & 4410.00 & 6675.00 \\
\hline & 85004 & 4545.00 & 7155.00 \\
\hline & 85005 & 6930.00 & 10965.00 \\
\hline & 85007 & 4050.00 & 6495.00 \\
\hline & Mean & 4984 & 7823 \\
\hline & SD & 1314 & 2113 \\
\hline
\end{tabular}

Abbreviations: Soy protein isolate (SPI), soy protein hydrolysate (SPH), whey protein isolate (WPI), whey protein hydrolysate (WPH), casein 
Table 5. Systolic Blood Pressure Area-Under-the-Curve (AUC) by Treatment

\begin{tabular}{|c|c|c|c|}
\hline Treatment & Subject ID & $\begin{array}{l}\text { AUC 60-180 } \\
\text { min }\end{array}$ & $\begin{array}{l}\text { AUC 0-180 } \\
\text { min }\end{array}$ \\
\hline \multirow{6}{*}{ Casein } & 85001 & 11280 & 16800 \\
\hline & 85004 & 15360 & 22830 \\
\hline & 85005 & 12045 & 18135 \\
\hline & 85007 & 14580 & 21195 \\
\hline & Mean & 13316 & 19740 \\
\hline & SD & 1961 & 2762 \\
\hline \multirow{6}{*}{ SPI } & 85001 & 11190 & 16860 \\
\hline & 85004 & 14790 & 22245 \\
\hline & 85005 & 13125 & 20250 \\
\hline & 85007 & 13320 & 20085 \\
\hline & Mean & 13106 & 19860 \\
\hline & SD & 1478 & 2228 \\
\hline \multirow{6}{*}{ SPH } & 85001 & 11625 & 17205 \\
\hline & 85004 & 16140 & 24480 \\
\hline & 85005 & 12810 & 19020 \\
\hline & 85007 & 13275 & 19875 \\
\hline & Mean & 13463 & 20145 \\
\hline & SD & 1915 & 3097 \\
\hline \multirow{6}{*}{ WPI } & 85001 & 11055 & 16770 \\
\hline & 85004 & 14715 & 22005 \\
\hline & 85005 & 12885 & 19230 \\
\hline & 85007 & 13320 & 19740 \\
\hline & Mean & 12994 & 19436 \\
\hline & SD & 1510 & 2148 \\
\hline \multirow{6}{*}{ WPH } & 85001 & 10890 & 16470 \\
\hline & 85004 & 15495 & 23850 \\
\hline & 85005 & 11730 & 17430 \\
\hline & 85007 & 13260 & 19680 \\
\hline & Mean & 12844 & 19358 \\
\hline & SD & 2022 & 3283 \\
\hline
\end{tabular}

Abbreviations: Soy protein isolate (SPI), soy protein hydrolysate (SPH), whey protein isolate (WPI), whey protein hydrolysate (WPH), casein 


\section{DISCUSSION:}

Differences between treatments were undetected and no treatment lowered SBP or inhibited ACE to any observable degree. Strengths include use of a cross-over design, inclusion of in vitro ACE activity measurements, and a diet controlling potassium and sodium for consistency with close monitoring of compliance. However, only an acute dose of $20 \mathrm{~g}$ was tested. This amount may be insufficient; studying the effects of multiple doses, or chronic dosing, over time would be more informative. Additionally, subjects were either mildly pre-hypertensive or normotensive; ACE-inhibitory potential may be more evident in pronounced hypertension. Other RAAS proteins were unevaluated to support or negate the proposition of ACE inhibition as the mechanism for reduced blood pressure. Finally, peptides were delivered in baked cookies. While heat stability in ACE-inhibitory activity was confirmed, stability to increased $\mathrm{pH}$ (potentially following added sodium bicarbonate and baking powder) is unknown. Although uncertain, $\mathrm{pH}$ and heat synergism and reactions occurring in heat conditions between proteins and reducing sugars, like the Maillard reaction, may influence bioactivity; these were not directly evaluated. Work is needed to determine optimal delivery to humans.

In conclusion, an acute dose of $20 \mathrm{~g}$ of either SPH or WPH when delivered in a uniquely formulated cookie did not reduce SBP or ACE activity. Discrepancies between in vitro ACE inhibition by SPH and WPH and inadequate in vivo evidence warrant further research, particularly to determine peptide bioavailability for optimal dosing to achieve biological effects.

Competing Interests: The study was funded by Dairy Management, Inc., a company with an interest in whey proteins. Dairy Management, Inc. reviewed the study protocol as part of the grant application review process without any role in the collection, analysis, or interpretation of the data.

Authors' Contributions: MM was responsible for data collection, analysis, and interpretation, and drafted this manuscript. SS assisted with protocol development, data interpretation, and the editing of this manuscript. BI was responsible for the preparation of SPI and hydrolysates, measurement of in vitro ACE inhibition of WPH and SPH, formulation of the treatment cookies, and assisted with editing the manuscript. RB executed statistical analyses, worked with MM and $\mathrm{CE}$ in data interpretation and presentation, and assisted with editing this manuscript. CE was the principal investigator responsible for protocol development, and overall project management and supervision of data collection, analysis and interpretation. CE provided guidance and editing on the manuscript as senior author.

Authors' Information: MM is a Graduate Research Assistant; this project was conducted as part of her Master of Science in Nutrition. SS is an Associate Professor of Medicine at the University of MN. RB is a Professor in the Department of Experimental and Clinical Pharmacology at the University of MN. BI is an Assistant Professor of Food Science at the University of MN. CE is an Associate Professor of Nutrition at the University of MN.

Acknowledgements: This project was funded by Dairy Management, Inc., administered by the Dairy Research Institute (to CP Earthman); the Minnesota Agricultural Experiment Station (to 
CP Earthman); and by Grant Number 1UL1RR033183 from the National Center for Research Resources (NCRR) of the National Institutes of Health (NIH) to the University of Minnesota Clinical and Translational Science Institute (CTSI). Its contents are solely the responsibility of the authors and do not necessarily represent the official views of the CTSI or the NIH. The University of Minnesota CTSI is part of a national Clinical and Translational Science Award (CTSA) consortium created to accelerate laboratory discoveries into treatments for patients.

We thank DCRU staff, Davisco Foods International, Inc. who provided the WPI and WPH, the Archer Daniels Midland Company who provided the soy flour samples, and ARUP Laboratories. We thank William Thomas, $\mathrm{PhD}$, who developed the randomization and initial statistical plan and reviewed the protocol; former graduate students Sara Vine and Sarah Kunkel who assisted in protocol development and data collection; Wynnie Margatan who prepared the soy proteins and measured in vitro ACE inhibition; Kristina Sandvik who prepared the treatment/cookies; and Bill Lendway who prepared the meals.

\section{REFERENCES:}

1. Nurminen M, Sipola M, Kaarto H, Pihlanto-Leppälä A, Piilola K, Korpela R, Tossavainen $\mathrm{O}$, Korhonen $\mathrm{H}$, Vapaatalo $\mathrm{H}$ : $\alpha$-Lactorphin lowers blood pressure measured by radiotelemetry in normotensive and spontaneously hypertensive rats. Life Sci 2000, 66:1535-1543.

2. Murakami, M., Tonouchi, H., Takahashi, R., Kitazawa, H., Kawai, Y., Negishi, H.,Saito, T.: Structural analysis of a new anti-hypertensive peptide ( beta-lactosin B) isolated from a commercial whey product. J Dairy Sci 2004, 87:1967-1974.

3. Lee Y, Skurk T, Hennig M, Hauner H: Effect of a milk drink supplemented with whey peptides on blood pressure in patients with mild hypertension. Eur J Nutr 2007, 46:21-27.

4. Jakala P, Turpeinen AM, Rajakari K, Korpela R, Vapaatalo H: Biological effects of casein-derived tripeptide powders are not affected by fermentation process. Int Dairy J 2010, 20:366-370.

5. Mizuno S, Matsuura K, Gotou T, Nishimura S, Kajimoto O, Yabune M, Kajimoto Y, Yamamoto N: Antihypertensive effect of casein hydrolysate in a placebo-controlled study in subjects with high-normal blood pressure and mild hypertension. $\mathrm{Br} J$ Nutr 2005, 94:84-91.

6. Jauhiainen, T., Ronnback, M., Vapaatalo, H., Wuolle, K., Kautiainen, H., Groop, P. H.,Korpela, R.: Long-term intervention with Lactobacillus helveticus fermented milk reduces augmentation index in hypertensive subjects. Eur J Clin Nutr 2010, 64:424-431.

7. Pins JJ, Keenan JM: Effects of whey peptides on cardiovascular disease risk factors. $J$ Clin Hypertens (Greenwich) 2006, 8:775-782.

8. Tsumura K, Saito T, Kugimiya W, Inouye K: Selective proteolysis of the glycinin and $\beta$ conglycinin fractions in a soy protein isolate by pepsin and papain with controlled $\mathrm{pH}$ and temperature. J Food Sci 2004, 69:C363-C367.

9. Margatan W, Markowski T., Ismail B.: Antihypertensive activity of soy protein subjected to selective hydrolysis. J Agric Food Chem 2012, submitted:. 
10. Otte J, Shalaby SM, Zakora M, Pripp AH, El-Shabrawy SA: Angiotensin-converting enzyme inhibitory activity of milk protein hydrolysates: Effect of substrate, enzyme and time of hydrolysis. Int Dairy J 2007, 17:488-503.

11. Shalaby SM, Zakora M, Otte J: Performance of two commonly used angiotensinconverting enzyme inhibition assays using FA-PGG and HHL as substrates. J Dairy Res 2006, 73:178-186.

12. Chiang WD: Angiotensin I-converting enzyme inhibitor derived from soy protein hydrolysate and produced by using membrane reactor. Food Chem 2006, 98:725.

13. Lo WMY, Farnworth ER, Li-Chan ECY: Angiotensin 1-converting enzyme inhibitory activity of soy protein digests in a dynamic model system simulating the upper gastrointestinal tract. . J Food Sci 2006, 71:S231-S237.

14. Lo W, Li-Chan E: Angiotensin I converting enzyme inhibitory peptides from in vitro pepsin-pancreatin digestion of soy protein. J Agric Food Chem 2005, 53:3369-3376.

15. Cha M, Park JR: Production and characterization of a soy protein-derived angiotensin Iconverting enzyme inhibitory hydrolysate. J Med Food 2005, 8:305-310.

16. Wu J: Characterization of inhibition and stability of soy-protein-derived angiotensin Iconverting enzyme inhibitory peptides. Food Res Int 2002, 35:367. 